\title{
\$sciendo
}

Ethics \& Bioethics (in Central Europe), 2020, 10 (1-2), 30-39

DOI:10.2478/ebce-2020-0004

\section{The limits of libertarianism in debates over euthanasia and the application of moral fictionalism in bioethics ${ }^{1}$}

\author{
Michal Trčka²
}

\begin{abstract}
This text focuses on selected basic arguments of libertarianism that could be found in certain debates on the moral issues of euthanasia and the application of moral fictionalism in bioethics. Firstly, I devote my article to the criticism of libertarian arguments (as one of the dominant discourses related to the debate over euthanasia) in a wider perspective of moral philosophy. The article is based on an approach that understands morality as a kind of social practice and the primary goal is to grasp the key theoretical concepts which are included in the mechanism for identifying and assessing our moral intuitions. This text is primarily an analysis of selected arguments of current normative theories of libertarianism on two levels: first it examines the idea of self-ownership in connection with certain debates over euthanasia, while the latter part of the article concerns an analysis of the critique of libertarian arguments and a comparison of the alternative arguments of moral fictionalism. The last part of this text, focusing on moral fictionalism and its general application in bioethics, is the core of the article.
\end{abstract}

Keywords: bioethics, euthanasia, liberalism, libertarianism, moral fictionalism, self-ownership

\section{Introduction}

Public debates on euthanasia have featured many difficult moral dilemmas. Some people offer as a universal solution to act according to the simple slogan "My body, my choice!" It's not only the slogan of some public demonstrations but this point of view belongs to the philosophical approach of libertarianism and partly also liberalism. It's a version of the wellknown libertarian concept/principle of self-ownership. Not only for this reason do I think that libertarianism is one version of current pre-theoretical moral beliefs. I also suppose that normative theories can partly influence our moral practices. For these reasons it is necessary to analyse this point of view and connected opinions. ${ }^{3}$

Firstly, in this article, I would like to focus on selected basic arguments of current normative theories of libertarianism on two levels: first of all I would examine the idea of self-ownership in connection with some debates on moral issues of euthanasia, while in the second part of my text, I shall focus on an analysis of the criticism of libertarian arguments, mainly the concept of self-ownership as one of the dominant discourses related to the debate on euthanasia. In some cases, I shall compare selected alternative arguments, but I don't want to defend certain current normative theories, e.g. evaluating euthanasia cases from perspective utilitarianism or Kantianism. The core of this article is the last part that concerns the application of moral fictionalism in bioethics. It is for me a general alternative approach to the issues of bioethics.

As for methodology, my approach is based on a wider perspective of moral philosophy. My analysis is based on an approach that understands morality as a kind of social practice.

\footnotetext{
${ }^{1}$ The paper was presented at the international conference End of Life and Euthanasia - Intersection of Issues and Questions held in Prague (Czech Republic) on 4-5 November 2019.

${ }^{2}$ Technical University of Liberec, Faculty of Science, Humanities and Education, Department of Philosophy, Liberec (Czech Republic); michal.trcka@tul.cz

${ }^{3}$ I view morality, as many thinkers do, as a kind of social practice, rather as an expression of theory. But moral theorizing is, according to this view, a part of moral practice. "It is a way of trying to ensure that the moralizing of ourselves and others is defensible [...] Moral theories, the abstract conceptions that we study in moral philosophy, are derivative of moral theorizing [...] We use these abstract structures for various purposes: to grade and categorize agents, acts, and outcomes; to relate to various religious beliefs and cultural outlooks; to evaluate, analyse, extend, and so on" (Jamieson, 1993, pp. 479-480).
} 
However, on the level of metaethics, I agree with the opinion that statements of moral philosophy about justice and other themes of morality are not empirically verifiable or falsifiable.

The primary, general goal of my analysis is to grasp the key theoretical concepts which are included in the mechanism for identifying and assessing our moral intuitions. Specifically, it means identifying the discrepancies in the concept of self-ownership and to test the concept of self-ownership and to use moral fictionalism as an alternative approach. I believe that the interpretation provided by libertarian philosophers is not very persuasive or suitable for debates about issues of euthanasia and general issues of bioethics.

\section{Libertarianism, self-ownership, and euthanasia}

The viewpoints that combine to make up libertarianism include many different opinions, however the concept of self-ownership is one of the main ideas (see Cohen, 1995). I apply the term libertarianism essentially as a rights-based ethical philosophy and I mean that the concept of self-ownership is probably used more by right-wing libertarians. But I don't make differences among various groups of libertarian thought in this presentation, e.g. left-wing or right-wing political libertarianism, since the motto or slogan "My body, my choice!" is used by many left- and right-wing representatives of libertarianism (see, e.g., Fabre, 2006). And it is necessary to add again that it is also used by some liberals.

A basic kind of the libertarian argument has the following form:

"1. Every moral agent is a self-owner. 2 . To be a self-owner implies very weighty rights over one's own body, as well as (under the right circumstances) weighty rights to acquire, hold, and transfer property at one's will. 3. For the modern nation-state to produce (most) regulation, paternalistic laws, public goods, and social insurance, it has to violate these rights. 4. Therefore, the modern nation-state is to that extent unjust" (Brennan \& van der Vossen, 2018, p. 200).

One of the founders of liberalism and an inspiration of libertarianism, John Locke, already assumed and claimed that the right to life is connected with the individual's ownership of his own body or life (see Locke, 1988). From this perspective, self-ownership is a core point, the basis of full rights of control. It means the right to determine the use of oneself, decisions may not be taken against a person without his/her consent against his/her will. More precisely, we can think of self-ownership as being made up of two variables: on the one hand, self-ownership offers protections against unwanted incursions on one's person; on the other hand, selfownership offers the freedom to use one's person (Brennan \& van der Vossen, 2018, p. 208). It offers a principled objection to clearly objectionable forms of paternalism or legal moralism (Brennan \& van der Vossen, 2018, p. 200). This view is based on the general liberal thesis that each person has the right to live their own life as they see fit, consistent with the same rights for others.

These views and opinions are also possible to find in debates about various medical issues. Most liberals agree that people at least have rights to make medical decisions about their bodies. For example, Jessica Flanigan defends a broadly libertarian approach to medicine and mainly argues against medical paternalism (Flanigan, 2017; Flanigan, 2018). Her main idea is that people's bodily rights extend beyond the mere right to refuse medical treatment and also include the right to choose and access medical treatment (Flanigan, 2018, p. 405).

This libertarian tradition of the opinion that we do own ourselves is also the foundation for some arguments in defense of the right to assisted suicide or a voluntary, non-compulsory kind of euthanasia. If a willing partner can be found, euthanasia is possible. This is not only a philosophical defense. Some liberal political philosophers claim that the right to autonomy must also be a constitutional right, if we want a guarantee of personal autonomy. In the case of 
euthanasia, people should be free to choose for themselves whether they wish to ask for the ending their life.

The liberal and libertarian statement of the right to die was established by Ronald Dworkin, Robert Nozick, Judith Thomson, John Rawls, T. M. Scanlon, and Thomas Nagel in 1997 for two Supreme Court cases that addressed whether patients had the constitutional right to die. In their text named 'The Philosophers' Brief', these thinkers argued that a person's interest in making end-of-life decisions is "[...] a central part of the more general right to make 'intimate and personal choices' for himself that a failure to protect that particular interest would undermine the general right altogether" (Dworkin et al., 1997). ${ }^{4}$

\section{The limits of libertarianism}

What are the problematic aspects contained in the slogan 'My body, my choice!' as a mirror of the concept of self-ownership? If we use the concept of self-ownership as an opinion of absolute ownership, this concept is highly controversial. For example, full self-ownership may permit voluntary enslavement because people have the right to control their own utilization. That's that they also have the right to transfer their rights over their persons to others, for example through sale or gift. However, some libertarians deny that these kinds of transfers are possible, e.g. it's morally impossible, because such transfers undermine our autonomy (Grunebaum, 1987).

The concept of self-ownership, statements like "My body, my choice!" or "I am the owner of my own body", are essentially metaphorical. The metaphorical character of this concept is maybe misleading or confusing. What is usually owned is something other than oneself as an embodied individual. The owner does not distinguish from what is owned in this case. But this is not such an essential objection as other more important objections.

Some libertarians use the self-ownership hypothesis as not based on an opinion of absolute ownership and reject full self-ownership. According to this view, we own different things in different ways, that is why rights that constitute ownership varies from thing owned to thing owned, and also the strength of these rights varies (Brennan \& van der Vossen, 2018, p. 208). As pointed out by some libertarians: "[...] disputes between libertarians and left liberals are not really about whether individuals are self-owners but rather about which conception of selfownership is the correct one" (Brennan \& van der Vossen, 2018, p. 200). In the debate between liberals and libertarians, the debate is over which liberties are basic and non-conventional. In the state of nature we cannot evaluate the justice of purported liberal rights. On face value, this argumentation works equally well against liberalism as it does against libertarianism. It is a very important point used when raising objections against this type of rights-based argumentation.

Weakened conceptions of self-ownership have a complicated structure. If self-ownership has multiple dimensions that can be weakened in light of competing considerations, it loses some of its theoretical appeal and then it is complicated to use it as a foundational principle. Libertarianism is also weakened in cases that deal with under-age persons. As a solution, it is proposed to make under-age children the responsibility of their parents, but this view means that the under-aged child is not a fully-fledged person. The same problem also comes up in the

\footnotetext{
${ }^{4}$ See also: “'The philosophers' brief' answers these questions in two steps. First, it defines a very general moral and constitutional principle - that every competent person has the right to make momentous personal decisions which invoke fundamental religious or philosophical convictions about life's value for himself. Second, it recognizes that people may make such momentous decisions impulsively or out of emotional depression, when their action does not reflect their enduring convictions; and it therefore allows that in some circumstances a state has the constitutional power to override that right in order to protect citizens from mistaken but irrevocable acts of selfdestruction. States may be allowed to prevent assisted suicide by people who - it is plausible to think would later be grateful if they were prevented from dying" (Dworkin et al., 1997).
} 
case of incompetent individuals. A solution is that someone close to the incompetent patient should make decisions for that patient. There are, for example, dangers of conflicts of interests between the decisions of a patient and family members or others surrogates.

The slogan 'My body, my choice!' and the concept of self-ownership is connected to the idea that a person is differentiated from other people as an individual agent. This idea doesn't indicate the social level of an individual life. But the decision to die by euthanasia affects other people. In the case of assisted suicide, the patient needs someone who practices euthanasia. There is also the need of a health system. This system needs institutionalized rules for the practice of legal euthanasia. And it is not possible, without the social consensus and the forced solidarity of those who refuse to join the consensus even if assisted suicide is legal only on a purely private basis, because such transactions would have to enjoy state protection like any other market transaction. The decision for one particular euthanasia is the decision of one particular person. But the possibility of legal, institutionalized assisted suicide is the decision of the whole society. ${ }^{5}$

I think that if we deny the concept of self-ownership, we can also question the form of the libertarian and liberal concept of autonomy. As already mentioned, liberal and libertarian political philosophers claim that there is the right for autonomy that should be the constitutional right to assisted suicide. They say: if we should guarantee some other rights in the name of autonomy so that the people can be free to choose for themselves, should it be the freedom to ask for the assistance of a physician in ending their life.

According to the contemporary philosopher Michael Sandel (Sandel, 2010), we need to engage with the moral ideas underlying our political debates, and I add, including the issues of euthanasia. In the case of euthanasia the question arises: would a constitutional law in the name of autonomy, guaranteeing the right to physician-assisted suicide, be neutral among competing conceptions of the good life? His answer is that autonomy-based right to assisted suicide would change the law in favour of one of the notions of the good life. Because not all moral views think of life or of a good life as a product of a human creation, as human beings or as the possession of the person who lives it (see also Sandel, 2015).

The conception of the good life according to a person's autonomy as a basis to defend a right to assisted suicide may not even be acceptable for many liberal philosophers who defend the concept of autonomy. For example, current Kantian philosophers also defend the right to assisted suicide because it guarantees our personal dignity (see Hill, 1991; Dworkin, 1993). But Immanuel Kant rejected the idea that we have the right to suicide, it's at odds with autonomy (Kant, 1964, p. 398). According to Kant's perspective, one's own life isn't one's own, it's not a possession, because moral law commands respect for humanity. ${ }^{6}$

It does not follow from these notions that libertarians are wrong to defend a terminally ill patient's right to choose assisted suicide under certain conditions. But the debate over assisted suicide and the debate about the liberal and libertarian form of autonomy isn't really neutral among competing conceptions of the good life, or of the best way to live.

\footnotetext{
${ }^{5}$ In this paragraph, I was inspired by the philosopher M. Škabraha's reflection on assisted reproduction (Škabraha, 2016).

${ }^{6}$ Sandel also comments on this point of view in this way: "His [Kant] point is that only the motive of duty - doing something because it's right, not because it's useful or pleasing or convenient - confers moral worth on an action. He illustrates this point with the example of suicide. Most people go on living because they love life, not because they have a duty to do so. Kant offers a case where the motive of duty comes into view. He imagines a hopeless, miserable person so filled with despair that he has no desire to go on living. If such a person summons the will to preserve his life, not from inclination but from duty, then his action has moral worth. Kant does not maintain that only miserable people can fulfill the duty to preserve their lives. It is possible to love life and still preserve it for the right reason - namely, that one has a duty to do so. The desire to go on living doesn't undermine the moral worth of preserving one's life, provided the person recognizes the duty to preserve his or her own life, and does so with this reason in mind" (Sandel, 2010, pp. 113-114).
} 
To claim certain rights means to make certain claims on society. But in order to create the conditions for fulfilling those demands, society must reciprocally place certain claims on us as individuals. The concrete degree of fulfillment of rights and obligations is connected with social debate, disputes, conventions and laws. It is important know that rights are neither natural nor universal. ${ }^{7}$

We attribute rights to each other in response to the experience that we as a society (or humanity) experience. Maximizing personal freedom, compatible with the same degree of freedom for others, is a principle that, according to our historical experience, helps to create a better society, with better decision-making processes. Human rights are a tool to build such a society. But these tools are useless if we understand rights as a kind of individual property and not as something that is rooted in reciprocity and thus in the ability to empathize with others and to understand their desire for the best life possible. ${ }^{8}$

\section{Moral fictionalism and its application in bioethics}

Bioethics is applied ethics that focuses on specific moral issues such as euthanasia. In my opinion, the above mentioned limits of libertarianism in the debate on euthanasia show certain general errors in thinking about normative judgments. Therefore, it is also necessary to remove these errors from the general debate on bioethical issues. In this section, firstly, I focus on how to discuss ethics, moral norms and values. Secondly, I try to show how this approach could be applied in the field of bioethics.

The issues of morality and moral judgment are dealt with the philosophical discipline of metaethics. "For among its central questions are the questions whether any moral claims are true, and whether it is rational to commit oneself to acting morally" (Copp, 2006, p. 6). ${ }^{9}$ David Hume was among the first significant modern critics of our natural understanding of morality from metaethical positions. He believes that when we use normative term 'ought to' in our moral judgements, we have to explain and also express some new relation or affirmation that has arisen from using this term. It is necessary to observe and explain it. ${ }^{10}$ According to my

\footnotetext{
${ }^{7}$ I would like to refer to some basic notes made by the historian and philosopher Y. N. Harari. In his popular TED speech titled What explains the rise of humans? Harari says: "Take a human being, cut him open, look inside, you will find the heart, the kidneys, neurons, hormones, DNA, but you won't find any rights. The only place you find rights are in the stories that we have invented and spread around over the last few centuries. They may be very positive stories, very good stories, but they're still just fictional stories that we've invented" (Harari, 2015). Basically, this is a popular version of moral theories of cognitivist realism or cognitivist anti-realism. It is also my point of view.

${ }^{8}$ Other types of arguments dedicated to the problems with 'Assisted suicide: The philosophers' brief' made F. M. Kamm (Kamm, 2013, pp. 42-52). She presents these counterarguments: “(i) that intending patients' deaths against their wishes does not alone make not-aiding impermissible, and (ii) that whether in the presence or absence of intending patients' deaths against their wishes, killing can be impermissible while letting die is not impermissible" (Kamm, 2013, p. 44).

${ }^{9}$ In more detail: "In meta-ehics we are concerned not with questions which are the province of normative ethics like 'Should I give to famine relief?', or 'Should I return the wallet I found in the street?', but rather with questions about questions like these. What does the 'should' in such question mean? Does it signal that these questions are about some matter of facts? If so, then how do we justify giving one answer rather than another? In other words, what sort of facts are moral facts? In what sense is a moral argument simply a species of rational argument? And if the 'should' does not signal that moral questions are about a matter of fact then, again, how do we justify giving one answer rather than another to such questions? In other words, what is its point of function? What is the standard against which a good moral argument is to be measured?" (Smith, 1994, p. 2).

10 "In every system of morality, which I have hitherto met with, I have always remark'd, that the author proceeds for some time in the ordinary way of reasoning, and establishes the being of a God, or makes observations concerning human affairs; when of a sudden I am surpriz'd to find, that instead of the usual copulations of propositions, is, and is not, I meet with no proposition that is not connected with an ought, or an ought not. This change is imperceptible; but is, however, of the last consequence. For as this ought, or ought not, expresses some new relation or affirmation, 'tis necessary that it shou'd be observ'd and explain'd; and at the same time that a reason shou'd be given, for what seems altogether inconceivable, how this new relation can be a deduction from
} 
counter-arguments mentioned above, I believe that libertarianism does not meet the demands of Hume's critique.

Due to the scope of my article, I cannot focus on other tests of normative ethics, such as Moore's Open Question Argument, ${ }^{11}$ in general (not only against libertarianism), therefore I will try to propose an alternative approach in a straightforward manner. First, one thing needs to be taken into account. The findings of evolutionary biology, psychology and ethics show that morality is a somewhat natural feature of human nature, but that does not mean that our moral judgements reflect objective reality or the realm of objective moral facts (see Haidt, 2012). As Richard Joyce, whose concept of morality I will discuss further, writes, the current research of human morality implies only that moral judgements operate to something more resembling encouraging successful social behavior (Joyce, 2006). ${ }^{12}$

In my opinion, so-called fictionalism is best resisted in debates about norms and beliefs in metaethics and ethics, because its goal is not to produce truths about reality. ${ }^{13}$ Fictionalism is intended as a theory with certain advantages, which it can offer without being true. That means we do not have to seek confirmation of our belief in the (universal) truthfulness of our morality - which in turn leads to errors (as in the analyzed case of libertarianism) -, because we are able to refute it with reason. But that does not necessarily mean a rejection of morality. A representative of fictionalism, M. E. Kalderon (2005), proposes accepting moral statements as if they were true (full acceptance) or temporary (tentative acceptance). The starting point of Joyce's moral fictionalism - Joyce being another author of this approach - is Mackie's 'Theory of Error'. Mackie claims that: "If there were objective values, then they would be entities or qualities or relations of a very strange sort, utterly different from anything else in the universe. Correspondingly, if we were aware of them, it would have to be by some special faculty of moral perception or intuition, utterly different from our ordinary ways of knowing everything else" (Mackie, 1977, p. 38). But Mackie argued that there are no moral facts and that all basic moral claims are false. ${ }^{14}$ According this theory moral facts do not exist, but with a connection with fictionalism we can see that fiction also evokes real emotions in us, which can motivate action, and for this reason fictions are also practical for our moral acts. Currently, this idea is being developed by Joyce. I will now concentrate especially on Joyce's concept of fictionalism in his book The myth of morality (Joyce, 2003).

Joyce holds the hypothesis that morality is an enhancement of reproductive fitness and the role of morality is to act as a kind of 'internalized authority' against the temptations of shortterm profit (Joyce, 2003, pp. 206-213). ${ }^{15}$ According to Joyce a different kind of advantage of moral thinking is that: (i) morality provides a strong foundation for 'moralistic aggression' towards variable defectors; (ii) moral framework "[...] may also provide something of a shared experience of value which binds a community together"; or (iii) morality is "[...] a familiar and widespread way of understanding our relations to each other, and therefore to abolish it

others, which are entirely different from it. But as authors do not commonly use this precaution, I shall presume to recommend it to the reader; and am perswaded, that this small attention wou'd subvert all the vulgar systems of morality, and let us see, that the distinction of vice and virtue is not founded merely on the relations of objects, nor is perceiv'd by reason" (Hume, 2007, p. 302).

${ }^{11}$ See Moore's book Principia Ethica (1993).

12 The cognitivist anti-realism of Joyce also stands the test of Moore's Open Question Argument.

${ }^{13}$ Apart from fictionalism, another approach that rejects the traditional notions of morality, is e.g. amoralism (see Mark, 2013).

14 "Mackie held that the moral properties, if there were any, would be intrinsically normative. Rightness would have "to-bedoneness" built into it. He thought that such a property would be 'queer', and unlike 'anything else in the universe'. He therefore concluded that there are no such properties (Copp, 2006, p. 9).

15 Joyce argues: "[...] the instrumental value of moral beliefs lies in their combating of weakness of will, their blocking of the temporary revaluing of outcomes that is characteristic of short-sighted rationalizations, their silencing of certain kinds of calculation" (Joyce, 2003, p. 215). 
entirely may bring anxiety and confusion" (Joyce, 2003, p. 228). And for this reason the moral fictions - and rules derived from them - may be practical instruments for our society and for our lives. And how can such statements and this philosophical position be useful for debates over issues of bioethics? Joyce in his book presents an example of the ethics committee of a hospital trying to work out the optimal and ethical means of allocating funds (Joyce, 2003, pp. 219-220). He writes:

\begin{abstract}
"Personally, I don't find it at all implausible to claim that combating the temptations of short-term profit is important even there. But even if that were not so it may still be useful to each individual if she thinks in moral terms since this will support and encourage her tendency of doing so in personal 'temptation situations' [...] Suppose that members of the hospital ethics committee are moral fictionalists [...] An important point to stress is that even if this were true, it would not follow that the deliberations of the committee are uncritical" (Joyce, 2003, p. 219).
\end{abstract}

The use of fictionalism brings several advantages over commonly accepted morality. I believe that the most important advantage is that it can make ethical decisions (in this specific situation decisions of the commission) without being bound by any particular morality. "The whole point of the moral fictive stance is that it is a strategy for staving off inevitable human fallibilities in instrumental deliberation" (Joyce, 2003, p. 223). Joyce also adds that the community may continue to require those who break agreements to suffer from 'moralistic aggression', or that those who do not sufficiently express such condemnation of opponents are themselves rejected. However, the motivation for such moral behavior in the case of moral fictionalism is different than in the case of common normative ethics.

The adoption of the above-mentioned and presented theories such as Hume's critique of normative thinking, Mackie's theory of error, or Joyce's theory of moral fictionalism, leads to the conviction that the moral character of man exists but there are no moral imperatives as separate moral facts. In my opinion, that is the reason why we need to take a position of pluralism when considering moral dilemmas or judgements. What does it mean to take a position of pluralism? Morality can be understood from several different basic perspectives. From the perspective of universalism, relativism, nihilism, or pluralism. From the perspective of universalism exist (in our debates on ethical issues) universally valid normative moral norms. From the position of relativism, it is claimed that morality is always relative, either because it is subjective or because it is culturally conditioned. According to the theories of nihilism, there is neither general truth nor general morality. However, pluralism means that we recognize the existence of moral systems (even only as social constructs) and measure and select their advantages and disadvantages. Pluralism is an approach to measure of values. We apply selected concepts in a social or personal value system, etc. The perspective of pluralism is thus interconnected both with the above mentioned fictionalism and with the evolutionary concept of morality as a mechanism of adaptation. ${ }^{16}$ Compared to that, universal ethical theories (such as libertarianism, kantianism, utilitarianism, but also strongly advocated liberalism) are controversial precisely because of their universalism, which can create a dogmatic position put forward as a universal truth.

I think that we need a critique of a particular attempt to derive normative conclusions form universalistic ethics in debates over issues of bioethics. This critique is presented in moral fictionalism. Applying this perspective to the debate about euthanasia means that we are looking for solutions that meet the criteria of 'usefulness', pragmatism, etc. This approach can

\footnotetext{
${ }^{16}$ It is also possible to define certain meta-ethical pluralism. Joyce points out how both moral naturalism and moral scepticism may be permissible positions: that certain forms of moral naturalism may be maintained, but the moral error theory may also be maintained (Joyce, 2006, pp. 89-105).
} 
also be called pragmatic empiricism. ${ }^{17}$ This kind of objective secular ethics satisfying the criteria of usefulness or pragmatism is e.g. a concept of Harm:

“[...] a system of 'everyday morality' which is founded on the concept of Harm, and which treats conduct as immoral primarily when it causes unjustifiable harm to others. This form of ethics does not presuppose any controversial theory of value, and it constitutes the viewpoint from which the author defends physician-assisted suicide. A doctor who helps a patient die - or who causes the patient's death on his own request - does not cause that individual harm if he/she has only a period of life filled with pain left" (Hř́bek, 2010, p. 749).

An important element of this article is to show moral fictionalism and its applications in bioethics. The arguments for moral fictionalism are used in opposition to libertarian arguments often found in the debate on the issue of euthanasia. The most important advantage of moral fictionalism is that it can make ethical decisions without being bound by any particular morality except scientific discoveries. On the other hand, the approach of moral fictionalism can have some weakness. Adopted fictionalism can be too abstract without a stable point for moral judgment and lead to wide pluralism. In this case, this ethics itself may become a source of decision paralysis. For this reason, moral fictionalism could be defined throughout some restrictive rules, regulating and limiting mechanisms, which are introduced to avoid overfilling the moral system. In this context, in debates on euthanazia, it is possible to use the abovementioned principles of compassion, protection and respect, or the concept of Harm. But also these concepts may be problematic, because they also have the significant disadvantage of ambiguity and variability. Therefore, the ethical approach of fictionalism needs another debate about its definiton, rules, regulating and limiting mechanisms.

\section{Conclusion}

We all take it for granted that we have a body. However, there is no subjectivity without intersubjectivity. It is the formation of the most individual - the personality and his/her inner life - that is most and most delicately dependent on reciprocal relationships with others. Does the body have to belong to someone? Is it not that I belong to my body at least to the same extent? The possessive pronoun in slogan "My body, my choice!" maybe isn't a practical idea for our debates on euthanasia, because in this slogan a person uses an idea of essentialism which is very controversial. It is necessary to view humanity and personality as something that is ascribed to the individual and what the individual further creates (and, in turn, affects the ideas of others, which in turn affect him/ her). None of us have our identity, personality, body, or even mind in our hands. 'Self-ownership' is an illusion. And it is necessary to say that it is a historical concept arising from liberalism and the so-called WEIRD morality: Western, Educated, Industrialized, Rich, Democratic systems of values (see Haidt, 2012). It's not a universally valid idea. Of course, if it is the act of decision itself, it must be taken on by the individual. However, if it is a decision-making process, it can be the decision of a number of additional votes or the whole society. I advocate moral fictionalism as an alternative approach

\footnotetext{
${ }^{17}$ Secular objectivistic moral theory is applied, e.g., in J. Rachels' The end of life: Euthanasia and morality (Rachels, 1986); or D. M. Hester provides this sort of moral approach in his book End-of-life care and pragmatic decision making, a philosophical framework based on a radically empirical attitude toward life and death: "As patients move through the dying process, our care for and about them must keep them in mind - not cookie-cutter care, but sensitive to their life stories and to those of their families and the communities of which they are a part. Taking seriously a radically empirical approach to patient care that encompasses patient experiences as integral to medical decision making, and helping to provide the space and tools for development of the final chapters in the lives of dying patients, is a morally significant act that we must continually take seriously, vigilant in our attempts to create some manner in which a peaceful death can prevail" (Hester, 2010, p. 161).
} 
to pragmatic empiricism, but it is still true that: "[...] so long as we live in a world of imperfect rationality and epistemological fallibility, morality has a place" (Joyce, 2003, p. 230). Applying this perspective to the debate on euthanasia and the issues of bioethics means that we are looking for solutions that meet the criteria of 'usefulness', pragmatism, etc.

I hope that I have pointed out some important arguments why it is better to substitute the concept of self-ownership although the limits of libertarianism arguments don't implicate that euthanasia is inherently morally wrong. The concept based on the notion of our body as property contains a number of issues. In the perspective I have presented, which is admittedly more complicated and less easily pictured than the metaphor of ownership, persons are what they are because of their relationships with one another. And this must be a foundational principle for our debates on euthanasia. I believe that better principles are compassion, protection and respect, or the concept of Harm.

\section{References}

BRENNAN, J. \& VOSSEN, B. van der (2018): The myths of the self-ownership thesis. In: J. Brennan, B. van der Vossen \& D. Schmidtz (eds.): The Routledge handbook of libertarianism. New York: Routledge, pp. 199-211.

COHEN, G. A. (1995): Self-ownership, freedom, and equality. New York: Oxford University Press.

COPP, D. (ed.) (2006): The oxford handbook of ethical theory. Oxford: Oxford University Press.

DWORKIN, R. (1993): Life's dominion. An argument about abortion, euthanasia, and individual freedom. New York: Alfred A. Knopf.

DWORKIN, R., NAGEL, T., NOZICK, R., RAWLS, J., SCANLON, T. \& THOMSON, J. (1997): Assisted suicide: The philosophers' brief, New York Review of Books 44 (March 27, 1997). [online] [Retrieved January 6, 2020] Available at: https://cyber.harvard.edu/bridge/ Philosophy/philbrf.htm

FABRE, C. (2006): Whose body is it anyway? Justice and the integrity of the person. Oxford: Clarendon Press.

FLANIGAN, J. (2017): Pharmaceutical freedom. Oxford: Oxford University Press.

FLANIGAN, J. (2018): A libertarian approach to medicine. In: J. Brennan, B. van der Vossen \& D. Schmidtz (eds.): The Routledge handbook of libertarianism. New York: Routledge, pp. 405-416.

GRUNEBAUM, J. (1987): Private ownership. New York: Routledge \& Kegan Paul.

HARARI, Y. N. (2015): What explains the rise of humans? In: TED Ideas worth spreading [online] [Retrieved January 13, 2020]. Available at: https://www.ted.com/talks/yuval_ noah_harari_what_explains_the_rise_of_humans

HESTER, D. M. (2010): End-of-life care and pragmatic decision making: A bioethical perspective. Cambridge: Cambridge University Press.

HŘIIBEK, T. (2010): Za etiku bez teologie. K článku Marka Váchy o eutanazii. [For ethics without theology: On Marek Vácha's article on euthanasia]. In: Filosofický časopis, 58(5), pp. 729-749.

HAIDT, J. (2012): The righteous mind: Why good people are divided. New York: Pantheon Books.

HILL, T. E. (1991): Autonomy and self-respect. Cambridge: Cambridge University Press. HUME, D. A. (2007): Treatise of human nature. Oxford: Clarendon Press.

JAMIESON, D. (1993): Method and moral theory. In: P. Singer (ed.): A companion to ethics. Oxford: Wilie-Blackwell, pp. 476-487.

JOYCE, R. (2003): The myth of morality. Cambridge: Cambridge University Press.

JOYCE, R. (2006): The evolution of morality. Cambridge: MIT Press. 
KALDERON, M. E. (2005): Moral fictionalism. Oxford: Clarendon Press.

KAMM, F. M. (2013): Bioethical prescriptions: To create, end, choose, and improve lives. Oxford: Oxford University Press.

KANT, I. (1964): Groundwork for the metaphysics of morals, trans. H. J. Paton, New York: Harper Torchbooks.

LOCKE, J. (1988): Two treatises of government. Cambridge: Cambridge University Press. MACKIE, J. L. (1977): Ethics. Inventing right and wrong. London: Penguin Books.

MARKS, J. (2013): Ethics without morals: In defense of amorality. New York: Routledge. MOORE, G. E. (1993): Principia Ethica. Cambridge: Cambridge University Press.

RACHELS, J. (1986): The end of life: Euthanasia and morality. Oxford \& New York: Oxford University Press.

SANDEL, M. (2010): Justice: What's the right thing to do? New York: Farrar, Strauss and Giroux.

SANDEL, M. (2015): Physician-assisted suicide. [online] [Retrieved January 13, 2020]. Avaliable at: https://www.youtube.com/watch?v=NRMRpqBSKNw

SMITH, M. (1994): The moral problem. Oxford: Blackwell.

ŠKABRAHA, M. (2016): Naše těla, naše volba [Our bodies, our choice]. In: Deník Referendum, October 16, 2016 [online] [Retrieved January 6, 2020] Available at: http://denikreferendum.cz/clanek/tisk/23925-nase-tela-nase-volba 